Avalaible online: https://ejournal.iai-tribakti.ac.id/index.php/pgmi Article doi: https://doi.org/10.33367/iiee.v1i.1335

\title{
Efektifitas Metode Pembelajaran Snowball Throwing Pada Mata Pelajaran IPA Kelas V SDIT Al Azhar Kota Kediri
}

\author{
Makhfud $^{1}$, Ali Imron ${ }^{2}$ \\ ${ }^{1}$ Institut Agama Islam Tribakti Kediri ${ }^{1}$, Institut Agama Islam Tribakti Kediri ${ }^{2}$ \\ ahmadgurah@gmail.com¹ ${ }^{1}$, aliimron2009@gmail.com²
}

\begin{abstract}
One of the learning problems is the accuracy of the teacher using the learning method. For schools, these problems are always motivated by the inability of teachers to choose and implement learning methods. In this context, it is important to study the effectiveness of the Snowball Throwing method in science subjects at SDIT AL Azhar Kediri. In order to obtain research results, the method used by researchers is descriptive qualitative. The data sources produced were the results of interviews, observations and document analysis. All data are processed and educated to be presented as research results. The results showed, the effectiveness of the Snowball Throwing learning method in science subjects at SDIT Al Azhar Kota Kediri is that it can improve student learning outcomes, the learning process becomes more enjoyable, can increase interest and motivation to learn, and can make students actively involved in learning.
\end{abstract}

Key Word: Effectiveness, Method, Snowball Throwing

\begin{abstract}
Abstrak
Salah satu permasalahan pembelajaran adalah ketepatan guru menggunakan metode pembelajaran. Bagi sekolah, permasalahan tersebut selalu dilatarbelakangi oleh ketidak mampuan guru dalam memilih dan melaksanakan metode pembelajaran. Dalam konteks inilah, penting mengkaji efektivitas metode Snowball Throwing pada mata pelajaran IPA di SDIT AL Azhar Kota Kediri. Guna mendapatkan hasil penelitian, metode yang dilakukan peneliti adalah kualitatif diskriptif. Sumber data yang dihasilkan adalah hasil wawancara, pengamatan dan analisis dokumen. Semua data diolah dan diredukasi untuk dipaparkan sebagai hasil penelitian. Hasil penelitian menunjukkan, efektifitas metode pembelajaran Snowball Throwing pada mata pelajaran IPA kelas SDIT Al Azhar Kota Kediri adalah dapat meningkatkan hasil belajar siswa, proses pembelajaran menjadi lebih menyenangkan, dapat meningkatkan minat dan motivasi belajar, serta dapat membuat siswa terlibat aktif dalam pembelajaran.
\end{abstract}

Kata Kunci: Efektifitas, Metode, Snowball Throwing 


\section{Pendahuluan}

Permasalahan pennggunaan metode pembelajaran sangat berdampak pada hasil pembelajaran yang diharapkan. ${ }^{1}$ Hal ini sangat dirasakan segenap pengelola lembaga pendidikan di Sekolah Dasar Islam Terpadu (SDIT) Al Azhar Kota Kediri. Permasalahan ini menjadikan dorongan kuat dari pengelola untuk meningkatkan skill dan kemampuan guru menerapkan metode pembelajaran.

Di SDIT, salah satu permasalahan yang tampak adalah kemampuan penggunakan metode pembelajaran Snowball Throwing. Metode Snowball Throwing merupakan salah satu metode pembelajaran yang dikembangkan berdasarkan Pendekatan Kontekstual (CTL). Snowball Throwing yang menurut asal katanya berarti 'bola salju bergulir' dapat diartikan sebagai model pembelajaran dengan menggunakan bola pertanyaan dari kertas yang digulung bulat berbentuk bola kemudian dilemparkan secara bergiliran di antara sesama anggota kelompok. ${ }^{2}$ Dilihat dari pendekatan yang digunakan dalam pembelajaran bahasa, etode snowball Throwing ini memadukan pendekatan komunikatif, integratif, dan keterampilan proses. ${ }^{3}$

Di SDIT AL Azhar Kota Kediri, sampai saat ini masih banyak guru-guru yang menggunakan metode pengajaran

${ }^{1}$ Arif S. Sadiman, dkk. Media Pendidikan, Pengertian, Pengembangan, dan Pemanfaatannya, Jakarta: PT. Raja Grafindo Persada, 2011),h, 21

2 Rahmad Widodo. (2012) Pengertian Snowball Throwing, diakses dari http://www.rumahbelajar.web.id/model- tradisional, hanya ceramah biasa. Kondisi ini ternyata membawa pengaruh pada siswa di dalam pembangunan pengetahuannya. Selain itu minat untuk mengikuti pelajaran rendah, seperti pelajaran IPA. Selain itu juga sarana laboratorium madrasah belum memadai, buku paket IPA sangat terbatas. Sehingga siswa murni belajar teori dan mendengarkan ceramah guru saja. Dilihat dari segi keaktifan siswa hanya menjadi obyek ceramah yang kurang mendapatkan kebebasan belajar model lain. Anak merasa bosan dan jenuh, tidak ada semangat belajar, sehingga membuat nilai anak didik rata-rata dibawah KKM yaitu 75. Para pengajar menjadi bingung me-ngapa prestasi anak tidak sesuai dengan harapan yang ditetapkan. ${ }^{4}$

Setelah mengevaluasi proses dan model pembelajarannya, akhirnya guruguru SDIT Al Azhar Kota Kediri, mengubah metode pembelajaran dengan menggunakan motode pembelajaran Snowball Throwing untuk meningkatkan kreatifitas dan hasil belajar siswa, meskipun tidak semua mata pelajaran. Setelah beberapa kali menerapkan metode pembelajaran snowball throwing peserta didik menjadi termotivasi untuk belajar kreatif, dan berkat kegigihan guru dalam merancang atau mengelola pembelajaran snowball throwing menjadikan prestasi anak

pembelajaran-snowball-throwing/ tanggal 26 Mei 2020

3 Rusman, Model-model Pembelajaran, (Jakarta: Raja Grafindo Persada,2013), h. 202 ${ }^{4}$ Dokumen evaluasi SDIT Al Azhar Tahun 
meningkat dari dibawah KKM menjadi diatas KKM rata-rata kelas 85. Di samping prestasi siswa rata-rata di atas KKM, juga pada tahun 2018 mendapat juara I lomba KSM (Kompetisi Sains Madrasah) tingkat Kecamatan, dan 3 tahun terakhir ini siswa lulusan SDIT Al Azhar Kota Kediri banyak yang diterima di MTsN dan SMP Negeri. ${ }^{5}$ Berpedoman pada penjelasan di atas, maka penulis tertarik untuk mengadakan penelitian dengan judul "Efektifitas Metode Pembelajaran Snowball Throwing pada mata pelajaran IPA Kelas V SDIT Al Azhar Kota Kediri".

\section{Metode}

Metode ini menggunakan pendekatan kualitatif diskripstif. Dalam penggalian data, metode ini menggunakan teknik wawancara, observasi dan dokumentasi. ${ }^{6}$ Semua dilakukan mulai 1 Januari sampai 31 Januari 2020 di Sekolah Dasar Islam Terpadu (SDIT) Al Azhar Kota Kediri. Prinsip dasar penelitian ini adalah kekuatan peneliti menafsirkan fenomena yang diteliti. Karena itu, peneliti secara spesifik meneliti pada pelajaran IPA Kelas $\mathrm{V}$ SDIT Al Azhar Kota Kediri”.

\section{Temuan dan Pembahasan}

Pembahasan dalam penelitian ini menjelaskan implementasi metode pembelajaran snowball throwing pada mata pelajaran IPA kelas V SDIT AL Azhar Kota Kediri, dan efektifitas metode pembelajaran snowball thro-wing pada mata pelajaran IPA kelas V SDIT AL Azhar Kota Kediri

\section{Implementasi}

Berdasarkan hasil wawancara dan observasi pada pembelajaran di kelas $\mathrm{V}$ sebelum guru kelas $\mathrm{V}$ menggunakan metode snowball throwing menunjukkan bahwa pembelajaran yang masih menggunakan metode konvensional seperti ceramah dan tanya jawab saja pembelajaran kurang maksimal karena siswa merasa tidak mempunyai motivasi dalam belajar IPA. ${ }^{7}$

Dalam pembelajaran belum sepenuhnya memahami materi yang disampaikan guru karena guru kurang maksimal dalam memberikan penjelas-an terkait dengan materi pelajaran IPA, guru kurang memberikan acuan pada siswa kurang mengefektifitaskan waktu dan guru kurang bisa menguasai kelas sehingga kelas kurang kondusif.

Sebelum penerapan metode snowball throwing ini masih banyak siswa yang kurang aktif dalam berdiskusi, siswa kurang konsentrasi dan kurang memperhatikan pelajaran. Jam terakhir pelajaran seringkali menjadi masalah dalam pembelajaran. ${ }^{8}$ Melihat siswa banyak yang mengantuk pada saat pelajaran jam terahir menjadi tantangan bagi guru untuk bisa menghilangkan situasi tersebut dalam proses belajar. Jika hal tersebut tidak cepat d iatasi, maka dapat dipastikan siswa menjadi pasif dan tidak termotivasi dalam belajar. Mungkin ini-

\footnotetext{
7 Ibu Nur guru kelas V SDIT AL Azhar Kota Kediri, di ruang guru, 21 Mei 2020

${ }^{8}$ Hasil laporan evaluasi SDIT AL Azhar Kota Kediri, 2019
} 
lah salah satu penyebab nilai siswa tidak dapat mencapai KKM. ${ }^{9}$

Untuk mengatasi hal tersebut, guru menerapkan metode pembelajaran yang dapat mengajak siswa bergerak secara fisik untuk menghindari kantuk, tentu saja tetap fokus pada pembelajaran, sehingga dapat meningkatkan kualitas belajar mereka dengan harapan prestasi mereka dapat meningkat.

Metode merupakan hal yang sangat penting dalam meningkatkan prestasi belajar. ${ }^{10}$ Keberadaan metode pembelajaran sangat dibutuhkan oleh tenaga pendidik untuk membantu tercapainya tujuan pengajaran, agar para peserta didik lebih cepat memahami apa yang disampaikan atau yang diajarkan oleh para guru. Hal ini juga berlaku pada siswa SDIT AL Azhar Kota Kediri untuk meningkatkan pemahaman dan hasil belajar siswa metode yang digunakan atau diterapkan adalah metode pembelajaran snowball throwing pada mata pelajaran IPA kelas V SDIT AL Azhar Kota Kediri, juga pada kelas-kelas lain hampir semua guru menerapkan metode pembelajaran snowball throwing pada pelajaran umum maupun agama.

Alasan perlunya menggunakan model Pembelajaran snowball throwing, adalah: 1) snowball throwing membantu menstrukturkan diskusi, 2) snowball throwing dapat meningkatkan partisipasi dan banyaknya informasi yang

9 Rusman, Model-Model Pembelajaran, (Jakarta: PT. Rajagrafindo Persada, 2013) h, 67

10 Rahmad Widodo. (2012) Pengertian Snowball Throwing, diakses dari http://www.rumahbelajar.web.id/model- dapat diingat oleh peserta didik, 3) snowball throwing meningkatkan kualitas peserta didik dalamdiskusi kelas, 4) peserta didik dapat mengembangkan kecakapan hidup sosial mereka karena melakukan diskusi dan berbagi dengan orang lain. ${ }^{11}$

Pelaksanaan snowball throwing pada tahap berpikir, setiap siswa berpikir secara mandiri untuk menjawab pertanyaan atau masalah yang diberikan guru. Pada tahap berpasangan, siswa secara berpasangan berdiskusi untuk menghasilkan jawaban bersama. Pada tahap berbagi, beberapa pasangan siswa diminta untuk mempresentasikan hasil diskusinya di dalam kelas. Dengan menggunakan Model Pembelajaran snowball throwing dalam pembelajaraan IPA di sekolah dasar dapat meningkatkan hasil belajar siswa menjadi lebih baik.

Pada dasarnya pembelajaran snowball throwing di SDIT Al Azhar kota Kediri ini merupakan bentuk pembelajaran dengan cara siswa belajar dalam kelompok-kelompok kecil secara kolabotarif yang anggotanya terdiri dari empat sampai enam orang dengan susunan anggota kelompok yang kemampuannya berbeda-beda, artinya dalam satu kelompok tidak murni dipilih yang pandai saja atau yang kurang mampu, melainkan dicampur sehingga dalam kelompok ada siswa yang mampu

pembelajaran-snowball-throwing/ tanggal 26 Mei 2020

${ }^{11}$ Edy Budiantoro. Pengaruh Penggunaan Model Pembelajaran Snowball Throwing Terhadap Aktivitas Belajar dan Penguasaan Materi, diakses dari http://jurnal.fkip.unila.ac.id/i tanggal 29 Mei 2020

el Bidayah: Journal of Islamic Elementary Education Volume 2, Nomor 2, September 2020 
membimbing teman-temannya, dalam pengelompokan ini didasarkan pada perpaduan antara minat dan bakat siswa dan latar belakang kemampuan siswa. Diharapkan dalam pembelajaran snowball throwing ini akan tercipta sebuah interaksi yang lebih luas, yaitu interaksi dan komunikasi yang dilakukan antara guru dan siswa, siswa dengan siswa dan siswa dengan guru.

Pada umumnya pembelajaran snowball throwing di SDIT Al Azhar Kota Kdiri ini berbertuan untuk:

a. Mengembangkan pemikiran siswa dalam melakukan kegiatan belajar agar lebih bermakna, baik dengan cara menemukan sendiri atau bekerja sama dengan teman dalam kelompok diskusi/pengamatan.

b. Melaksanakan sejauh mungkin kegiatan penemuan untuk semua topik materi yang diajarkan.

c. Mengembangkan sifat ingin tahu siswa melalui memunculkan pertanyaan-pertanyaan.

d. Menciptakan masyarakat belajar

e. Membiasakan siswa untuk bekerja sama dalam kelompok tertentu. ${ }^{12}$

Untuk mencapai keberhasilan dalam penggunaan metode pembelajaran snowball throwing, guru mata pelajaran IPA kelas V SDIT AL Azhar kota Kediri, juga menggunakan media pembelajaran berupa LCD atau proyektor, karena penggunaan LCD ini akan dapat memperjelas materi yang disampaikan, sehingga dapat mencegah atau membetulkan kesalah pahaman. Materi-materi

12 Rahmad Widodo. (2012) Pengertian Snowball Throwing, diakses dari http://www.rumahbelajar.web.id/modelpembelajaran-snowball-throwing/ tanggal 26 Mei 2020 yang sulit untuk dijelaskan karena keterbatasan pengamatan dapat dengan mudah dijelaskan dengan penggunaan LCD ini.

Penggunaan media LCD juga dapat membuat siswa lebih tertarik dan bersemangat dalam memahami pelajaran karena proses belajar dan mengajar lebih bervariasi, tidak semata-mata komunikasi verbal melalui penuturan kata-kata oleh guru, sehingga siswa tidak bosan dan guru tidak kehabisan tenaga Dengan media LCD ini dapat membangkitkan keinginan dan minat baru, membangkitkan motivasi dan rangsangan kegiatan belajar, dan bahkan membawa pengaruh-pengaruh psikologis terhadap siswa. ${ }^{13}$

Penerapan metode pembelajaran snowball throwing pada mata pelajaran IPA kelas V SDIT AL Azhar Kota Kediriini, ada perbedaan dengan teori yang dikembangkan oleh para ahli. Pada tahap tertentu teori para ahli menyebutkan bahwa siswa mengepal kertas hingga membentuk seperti bola, kemudian bola itu dilemparkan kepada teman, sedangkan teman yang lain ganti melemparkan atau saling melempar, sehingga suasana menjadi gaduh.

Untuk menghindari kegaduhan dan bahkan bisa memberikan kemanfaatan kepada siswa, maka guru-guru SDIT AL Azhar Kota Kediri, mengubah tidak melempar bola akan tetapi membentuk lingkaran sambil bernyanyi setiap siswa memberikan bola kertas pertanyaan keteman sampingnya, sam-

13 Kunandar Guru Profesional Implementasi Kurikulum Tingkat Satuan Pendidikan. (Jakarta: Raja Grafindo Persada, 2011),h.231 
pai seleseinya lagu nasional yang dinyanyikan. Pada akhir lagu siswa yang memegang bola kertas pertanyaan, maka dialah yang bertanggung jawab menjawab pertanyaan teman.

Jadi implementasi metode pembelajaran snowball throwing di SDIT AL Azhar Kota Kediri sebenarnya sama dengan teori para ahli, hanya diganti metode lemparan bola kertasnya dengan memberikan keteman sampingnya sambil menyanyikan sebuah lagu hingga selesei. Di sini juga terdapat unsur hiburan agar anak-anak tidak gampang bosan, lelah, dan capek.

Selama proses snowball throwing terjadi, suasana kelas sangat dinamis dan terdengar gaduh tetapi masih dalam koridor belajar. Siswa yang pada pertemuan sebelumnya mengantuk kini tidak lagi, karena mereka harus berkonsentrasi menerima lemparan soal dan menjawabnya. Siswa aktif dan semangat dalam membahas dan menyelesaikan materi yang dipelajari sehingga dapat meningkatkan hasil belajar siswa sesuai dengan yang diharapkan untuk dapat mencapai KKM.

Agar siswa merasa tidak jenuh dalam belajar, tidak merasa tertekan atau bahkan stres, kepala sekolah selalu menyarankan kepada guru IPA untuk menggunakan strategi mengajar yang bervariasi, tidak monoton seperti ceramah dan ceramah saja. ${ }^{14}$ Kepala Sekolah tidak jemu-jemunya memperbaiki dan mengembangkan metode mengajarnya, salah satu kiat yang saya sarankan supaya murid mersa gembira di kelas, guru IPA kelas $\mathrm{V}$ untuk tidak pasang wajah cemberut yang membuat siswa takut tetapi tersenyum sehingga siswa dapat merasa senang mengikuti jalannya pelajaran

Beberapa penelitian membuktikan bahwa perhatian anak didik berkurang bersamaan dengan berlalunya waktu. Penelitian Pollio menunjukkan bahwa siswa dalam ruang kelas hanya memperhatikan pelajaran sekitar $40 \%$ dari waktu pembelajaran yang tersedia. Sementara penelitian McKeachie menyebutkan bahwa dalam sepuluh menit pertama perthatian siswa dapat mencapai $70 \%$, dan berkurang sampai menjadi $20 \%$ pada waktu 20 menit terakhir. ${ }^{15}$

Guru itu memang harus kreatif, ini merupakan tanggung jawab profesi yang diembannya, guru harus bisa menggunakan dan mengembangkan metode snowball throwing sesuai dengan kondisi yang ada. Seperti di SDIT AL Azhar Kota Kediri ini, seluruh kegiatan pembelajaran harus menstimulasi ketiga ranah afektif, kognitif dan piskomotorik dengan menggunakan berbagai pendekatan belajar atau metode belajar. Sekarang belajar tidak boleh lagi hanya terpaku pada pembahasanpembahasan konsep dan teori belaka. Setiap pokok bahasan harus berupaya menarik minat anak terhadap pokok bahasan tersebut, serta membimbing mereka untuk masuk pada dunia aplikasinya, sehingga juga akan menumbuhkan semangat dan motivasi belajar yang tinggi, karena suasana

15 As'aril Muhajir (2010), Ilmu Pendidikan Perpektif Kontekstual, Arruz Media, Yogyakarta, h.1

el Bidayah: Journal of Islamic Elementary Education Volume 2, Nomor 2, September 2020 
menyenangkan dan menantang akan selalu mereka dapatkan.

Kebanyakan guru berbicara sekitar 100-200 kata per menit, sementara anak didik hanya mampu mendengarkan 50-100 kata per menitnya (setengah dari apa yang dikemukakan guru), karena siswa mendengarkan pembicaraan guru sambil berpikir. ${ }^{16}$

Penambahan visual pada proses pembelajaran dapat menaikkan ingatan sampai $171 \%$ dari ingatan semula. Dengan penambahan visual di samping auditori dalam pembelajaran kesan yang masuk dalam diri anak didik semakin kuat sehingga dapat bertahan lebih lama dibandingkan dengan hanya menggunakan audio (pendengaran) saja. Hal ini disebabkan karena fungsi sensasi perhatian yang dimiliki siswa saling menguatkan, apa yang didengar dikuatkan oleh penglihatan (visual), dan apa yang dilihat dikuatkan oleh audio (pendengaran). Dalam arti kata pada pembelajaran seperti ini sudah diikuti oleh reinforcement yang sangat membantu bagi pemahaman anak didik terhadap materi pembelajaran.

Penelitian mutakhir tentang otak menyebutkan bahwa belahan kanan korteks otak manusia bekerja 10.000 kali lebih cepat dari belahan kiri otak sadar. Pemakaian bahasa membuat orang berpikir dengan kecepatan kata. Otak limbik (bagian otak yang lebih dalam) bekerja 10.000 kali lebih cepat dari korteks otak kanan, serta mengatur dan mengarahkan seluruh proses otak kanan. ${ }^{17}$

Oleh karena itu sebagian proses mental jauh lebih cepat dibanding pengalaman atau pemikiran sadar seseorang. Strategi pembelajaran konvensional pada umumnya lebih banyak menggunakan belahan otak kiri (otak sadar) saja, sementara belahan otak kanan kurang diperhatikan. Pada pembelajaran dengan snowball throwing pemberdayaan otak kiri dan kanan sangat dipentingkan. Thorndike (Bimo Wagito, 1997) mengemukakan 3 hukum belajar, yaitu:

1. Law of readiness, yaitu kesiapan seseorang untuk berbuat dapat memperlancar hubungan antara stimulus dan respons.

2. Law of exercise, yaitu dengan adanya ulangan-ulangan yang selalu dikerjakan maka hubungan antara stimulus dan respons akan menjadi lancar

3. Law of effect, yaitu hubungan antara stimulus dan respons akan menjadi lebih baik jika dapat menimbulkan hal-hal yang menyenangkan, dan hal ini cenderung akan selalu diulang. ${ }^{18}$

Dalam penerapan metode snowball throwing di kelas V SDIT Al Azhar Kota Kediri, masih ada sebagian siswa mengalami kesulitan, diantaranya belum bisa bekerja sama, dan menyampaikan materi kepada teman-temannya, belum bisa menyusun pertanyaan sendiri. Maka untuk mengatasi kesulitan

18 As'aril Muhajir (2010), Ilmu Pendidikan Perpektif Kontekstual. h. 59

\footnotetext{
dikan Perpektif Kontekstual, h.50

17 As'aril Muhajir (2010), Ilmu Pendi-

16 As'aril Muhajir (2010), Ilmu Pendi- 
siswa tersebut, guru harus bisa menanamkan pemikiran bahwa:

1. Siswa dalam kelompok harus beranggapan bahwa mereka se-hidup sepenanggungan bersama.

2. Siswa bertanggung jawab atas segala sesuatu di dalam kelompoknya, seperti milik mereka sendiri

3. Siswa harus melihat bahwa semua anggota di dalam kelompoknya memiliki tujuan yang sama.

4. Siswa haruslah membagi tugas dan tanggung jawab yang sama diantara anggota kelompoknya.

5. Siswa akan dikenakan evaluasi atau hadiah/penghargaan yang juga akan dikenakan untuk semua anggota kelompok. ${ }^{19}$

Di samping siswa mengalami kesulitan dalam pembelajaran snowball throwing, guru pun mengalami kesulitan dalam menerapkannya, yang seharusnya guru lebih berperan sebagai fasilitator yang berfungsi sebagai jembatan penghubung ke arah pemahaaman yang lebih tinggi, dengan catatan siswa sendiri, guru tidak hanya memberikan pengetahuan pada siswa, tetapi juga harus membangun pengetahuan dalam pikirannya, sehingga siswa mempunyai kesempatan untuk mendapatkan pengalaman langsung dalam menerapkan ideide mereka, tetapi nyatanya guru lebih banyak menjadi tutorial bagi siswa sehingga siswa sulit mengem-bangkan ide-ide sendiri. ${ }^{20}$

19 Rahmad Widodo. (2012) Pengertian Snowball Throwing, diakses dari http://www.rumahbelajar.web.id/modelpembelajaran-snowball-throwing/ tanggal 26 Mei 2020

20 Kunandar Guru Profesional Implementasi Kurikulum Tingkat Satuan 18
Untuk mengatasi permasalahan tersebut, barang kali guru banyak melatih siswa untuk mengamati peristiwa yang terjadi di sekitar, kemudian menyimpulkan permasalahan peristiwa tersebut dan menyampaikan kepada teman-temannya di depan kelas, dengan cara membaca ringkasan dari peristiwa yang di peroleh dan teman yang lain memberikan komentar. Ini dimaksudkan untuk melatih siswa agar bisa mengembangkan pikirannya sendiri, tidak hanya memperoleh pengetahuan dari guru saja, kemudian menyampaikan informasinya kepada teman sekelas supaya siswa terbiasa memberikan pengetahuan kepada yang membutuhkan, sehingga dalam pembelajaran snowball throwing siswa siap menjadi tutor sebaya. $^{21}$

Memang dalam pembelajaran snowball throwing ini akan tercapai apabila:

1. Guru menekankan akan pentingnya usaha bersama di samping usaha secara individual.

2. Guru menghendaki pemerataan perolehan hasil dalam belajar.

3. Guru ingin menanamkan tutor sebaya atau belajar melalui teman sendiri.

4. Guru menghendaki adanya pemerataan partisipasi aktif siswa.

5. Guru menghendaki kemampuan siswa dalam memecahkan berbagai per-masalahan.

Pendidikan. (Jakarta: Raja Grafindo Persada, 2011),h.231

${ }_{21}$ Lorin W Anderson, Dkk. Kerangka Landasan Untuk Pembelajaran Pengajaran Asesmen. (Yogjakarta: Pustaka Pelajar, 2014), h. 89 
Memang metode pembelajaran snowball throwing disamping memiliki kelebihan juga ada kekurangannya, begitu pula penerapan metode ini di SDIT Al Azhar Kota Kediri masih ada kekurangannya, yaitu: (1) sulit dalam mengontrol anggota kelompok yang lain saat ketua kelompok maju untuk menerima panjelasan tentang materi, dengan kata lain kelas menjadi gaduh dan kurang kondusif, (2) ketua kelompok yang dipilih secara random tanpa memperhatikan kemampuan ketua kelompok, membuat guru memerlukan waktu yang lama untuk membuat ketua kelompok memahami materi hingga selanjutnya dapat menjelaskan kembali pada anggotanya, (3) materi yang pendek yang terdapat pada buku diktat atau LKS mengakibatkan peserta didik tak jarang membuat pertanyaan yang sama walaupun cara penyampaiannya berbeda, (4) adanya peserta didik yang bergantung pada peserta didik yang lain. ${ }^{22}$

Kelemahan dalam metode snowball throwing ini dapat diatasi dengan cara berikut: 1) memisahkan group anak yang dianggap sering membuat gaduh dalam kelompok yang berbeda. Selain itu guru juga dapat ikut serta dalam pembuatan kelompok, sehingga kegaduhan bisa diatasi. 2) Guru menerangkan terlebih dahulu materi yang akan dibahas secara singkat dan jelas disertai dengan aplikasinya. Saran yang lain yang dapat digunakan untuk permasalahan kedua yaitu mengoptimalisasi waktu dengan cara memberi batasan dalam pembuatan kelompok dan pembuatan pertanyaan, sehingga waktu dapat digunakan untuk kegiatan yang lain. 3) Peserta didik yang memiliki pertanyaan yang sama diminta untuk tunjuk jari dan menjawab pertanyaan tersebut pada kesempatan yang sama. 4) Pada satu kelompok peserta didik tidak diperbolehkan membuat pertanyaan yang sama, sehingga peserta didik harus berpikir sendiri untuk membuat pertanyaan.

Adapun kualifikasi untuk guruguru yang mengajar menggunakan metode pembelajaran snowball throwing di SDIT Al Azhar Kota Kediri, adalah:

a. Guru mempunyai kemampuan lebih sesuai bidangnya masing-masing atau kompetensi profesionalnya.

b. Guru mempunyai motivasi untuk mengembangkan diri dalam menguasai metode-metode pembelajaran. $^{23}$

2. Efektivitas metode pembelajaran Snowball Throwing pada Mata Pelajaran IPA kelas V SDIT AL Azhar Kota Kediri

Saat observasi di kelas, peneliti menemukan fakta bahwa peserta didik di kelas tidak ada lagi yang mengeluhkan tidak suka dengan mata pelajaran IPA yang diajarkan dengan menggunakan metode snowball throwing, mereka cenderung bersemangat untuk menerima mata pelajaran. Dengan demikian, metode snowball throwing efektif dan

Asesmen. (Yogjakarta: Pustaka Pelajar, 2014), h.

\footnotetext{
Kepala SDIT AL Azhar Kota Kediri, 12 April 2020

23 Lorin W Anderson, Dkk. Kerangka Landasan Untuk Pembelajaran Pengajaran el Bidayah: Journal of Islamic Elementary Education Volume 2, Nomor 2, September 2020
}

22 Hasil wawancara dengan Ibu Naning 89 
dapat digunakan dalam pembelajaran IPA. Metode ini juga membuat peserta didik lebih aktif sehingga peserta didik bersemangat untuk mengikuti pelajaran IPA.

Sesuai dengan uraian dan penjelasan paparan data diatas maka dapat diambil kesimpulan bahwa efektifitas metode pembelajaran snowball throwing antara lain::

1. Dapat meningkatkan hasil belajar siswa

Berdasarkan hasil penelitian diketahui bahwa terdapat peningkatan hasil belajar pembelajaran melalui metode pembelajaran snowball thorwing. Hal tersebut diindikasikan dari perolehan rata-rata yaitu sebesar 90 di atas ratarata KKM yang hanya 75 .

Kemajuan siswa ini terlihat dalam hal keberanian siswa ketika mengemukakan pendapat. Siswa mulai berani mengemukakan pendapatnya, hal ini terlihat dari keaktifan siswa bertanya tentang materi yang belum dimengerti. Siswa juga tidak malu lagi menjawab pertanyaan, setiap siswa selalu berusaha menjawab pertanyaan dengan benar tanpa malu-malu lagi. Keberanian siswa juga semakin terlihat ketika harus tampil di depan kelas, mereka berani tampil mengemukakan rangkuman materi di depan kelas.

Perilaku lain yang menunjukkan peningkatan siswa yaitu dalam hal ketepatan. Tugas yang diberikan kepada siswa dapat diselesaikan dengan baik walaupun belum semuanya dapat diselesaikan tepat waktu. Hal lain yang meningkat yaitu kemampuan siswa dalam menjawab pertanyaan. Selain itu dalam membuat pertanyaan, siswa mampu membuat pertanyaan sesuai materi yang sedang dipelajari. Siswa belum dapat menyelesaikan tugas lebih awal dari waktu yang ditentukan. Hal ini dikarenakan siswa sudah terbiasa menyelesaikan tugas dengan cepat.

Kemampuan mengajar guru juga ada peningkatan walaupun belum signifikan. Guru sudah mulai mengelola ruang, fasilitas, strategi, interaksi dengan siswa, dan evaluasi dengan baik. Namun untuk pengelolaan waktu masih belum dapat terlaksana dengan efektif, karena guru belum terbiasa menggunakan metode pembelajaran snowball throwing. Kesan umum guru dalam mengajar masih sedikit kaku, kurang luwes dan belum terlalu peka terhadap kondisi siswa.

Jadi ini membuktikan bahwa penerapan metode pembelajaran snow-ball thorwing dapat meningkatkan hasil belajar siswa. Disamping aspek kognitif siswa, penerapan metode tersebut juga mampu meningkatkan aspek afektif dan psikomotor. Aspek afektif yang tampak yakni kesungguhan, keberanian, sementara aspek psikomotor dapat dilihat dari kecepatan dan ketepatan siswa menyelesaikan serangkai tugas.

Dengan demikian dapat ditarik kesimpulan bahwa efek menerapkan metode pembelajaran snowball throwing, dapat meningkatkan hasil belajar siswa pada mata pelajaran IPA kelas $\mathrm{V}$ SDIT Al Azhar Kota Kediri.

2. Dapat Membuat Proses Pembelajaran Lebih Menyenangkan

Dengan menggunakan metode pembelajaran snowball throwing akan membuat proses pembelajaran menjadi 
lebih menyenangkan karena ditunjang dengan inovasi yang tidak monoton, yang dapat menarik perhatian siswa, sehingga dengan penggunaan metode snowball throwing proses pembelajaran di kelas menjadi menyenangkan.

3. Dapat Meningkatkan Minat dan Motivasi Belajar.

Dengan menggunakan metode pembelajaran snowball throwing para peserta didik kelas V SDIT AL Azhar Kota Kediri menjadi lebih bersemangat belajar, karena proses belajar mengajar lebih.

4. Dapat membuat siswa terlibat aktif dalam pembelajaran.

Dengan menggunakan metode pembelajaran snowball throwing, peserta didik kelas V SDIT AL Azhar Kota Kediri menjadi lebih aktif bekerja sama dengan temannya dalam kelompok yaitu aktif berfikir juga aktif fisiknya.

Dari berbagai hasil temuan di atas mengenai efektifitas metode pembelajaran snowball throwing pada mata pelajaran IPA kelas V SDIT AL Azhar Kota Kediri ternyata banyak sekali efektifitas penggunaan metode pembelajaran tersebut diantaranya adalah dapat meningkatkan hasil belajar siswa, proses pembelajaran menjadi lebih menyenangkan, dapat meningkatkan minat dan motivasi belajar, dapat membuat siswa terlibat aktif dalam pembelajaran. Efektifitas tersebut sangat menunjang proses pembelajaran di SDIT AL Azhar Kota Kediri

Jadi dapat disimpulkan bahwa penggunaan metode pembelajaran snowball throwing pada mata pelajaran
IPA dan mata pelajaran lain di kelas $\mathrm{V}$ atau kelas atas bawah SDIT AL Azhar Kota Kediri sangat efektif untuk diterapkan, karena dapat meningkatkan hasil belajar siswa, dapat membuat proses pembelajaran lebih menyenangkan, dapat meningkatkan minat dan motivasi belajar, serta dapat membuat siswa terlibat aktif dalam proses pembelajaran.

Disamping itu metode pembelajaran snowball throwing efektif diterapkan di SDIT AL Azhar Kota Kediri, karena dapat menumbuh kembangkan potensi intelektual sosial, dan emosional yang ada di dalam diri murid, serta dapat melatih murid mengemukakan gagasan dan perasaan.

\section{Kesimpulan}

Salah satu cara mengatasi permasalahan yang mengambat hasil belajar di SDIT AL Azhar Kota Kediri Kelas $\mathrm{V}$ pada mata IPA dengan menerapkan metode snowball throwing. Hasilnya, prestasi belajar meningkat yang dibuktikan dengan nilai yang diperoleh siswa rata-rata 90.

\section{Daftar Pustaka}

Agus Suprijono. (2011) Cooperative Learning. Pustaka Pelajar, Yogyakarta

Arif S. Sadiman, dkk. (2011) Media Pendidikan, Pengertian, Pengembangan, dan Pemanfaatannya, PT. Raja Grafindo Persada, Jakarta

As'aril Muhajir. (2010) Ilmu Pendidikan Perpektif Kontekstual, Arruz Media, Yogyakarta

Edy Budiantoro. (2016) Pengaruh Penggunaan Model Pembelajaran 
Snowball Throwing Terhadap Aktivitas Belajar dan Penguasaan Materi, diakses dari http://jurnal.fkip.unila.ac.id/index.php/JBT/art icle/view/2717 tanggal 29 Mei 2020

Herdian. (2014) Penggunaan Model Snowball Throwing Untuk meningkatkan hasil belajar siswa pada materi sistem pencernaan manusia di kelas VIII SMPN 4 Minas, diakses dari http://unilak.ac.id/media/file/96 229412825897532291246. pdf tanggal 1 Juni 2020

H.B. Sutopo. (2006) Metodologi Penelitian Kualitatif:dasar tiori dan terapannya dalam penelitian. Universitas Sebelas Maret, Surakarta

Kunandar. (2011) Guru Profesional Implementasi Kurikulum Tingkat Satuan Pendidikan. Raja Grafindo Persada, Jakarta

Lexy J. Moleong. (2013) Metodologi Penelitian kualitatif, Remaja Rosdakarya, Bandung

Lorin W Anderson, Dkk. (2010) Kerangka Landasan Untuk Pembelajaran Pengajaran Asesmen. Pustaka Pelajar, Yogyakarta

Moleong, Lexy J. (2007) Metodologi Penelitian Kualitatif. Remaja Rosda karya, Bandung

Mukhlisah, Dkk. (2009).Teori Belajar dan Aplikasinya pada Pembelajaran di MI, LPTK Fakultas Tarbiyah IAIN Sunan Ampel, Surabaya

Prasetya Irawan. (1999) Logika dan Prosedur Penelitian: Pengantar
Teori dan Panduan Praktis Penelitian Sosial bagi Mahasiswa dan Peneliti Pemul, STAIN, Jakarta

Program PascaSarjana Magister Pendidikan Agama Islam IAIT Kediri. (2014) Panduan Penulisan dan Tata Cara Penyelenggaraan Ujian Proposal dan Tesis.

Rahmad Widodo. (2012) Pengertian Snowball Throwing, diakses dari http://www.rumahbelajar.web.id /model-pembelajaran-snowballthrowing/ tanggal 26 Mei 2020

Robert E. Slavin. (2005) Cooperative Learning: Theory, Research and Practice (N. Yusron. Terjemahan). Allymand Bacon, London

Rusman. (2013) Model-model Pembelajaran. Raja Grafindo Persada, Jakarta

Sanapiah Faisal. (1990) Penelitian Kualitatif: Dasar-Dasar dan Aplikasi, YA3, Malang

Wina Sanjaya. (2005) Pembelajaran dalam Implementasinya kurikulum berbasis Kompetensi, Fajar Interpratama Offset, Jakarta 